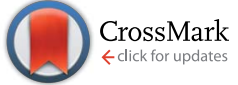

Cite this: RSC Adv., 2014, 4, 31047

Received 13th May 2014

Accepted 23rd June 2014

DOI: $10.1039 / \mathrm{c} 4 \mathrm{ra0} 4511 \mathrm{~d}$

www.rsc.org/advances

\section{Hierarchical cystine flower based electrochemical genosensor for detection of Escherichia coli O157:H7†}

\begin{abstract}
Chandra Mouli Pandey, ${ }^{\text {ab }}$ Ida Tiwari ${ }^{\mathrm{b}}$ and Gajjala Sumana*a
This work reports on a facile and reproducible approach to synthesize novel organic flowers of cystine (CysFls) with high uniformity. These 3D flower-like structures have a purely hierarchical arrangement, wherein each petal is composed of several cystine molecules with an average size of $50 \mu \mathrm{M}$, as determined by transmission electron microscopy. The CysFls were self-assembled onto a gold electrode and were utilized as matrices for the covalent immobilization of an Escherichia coli O157:H7 (E. coli) specific probe oligonucleotide that was identified from the $16 \mathrm{~s}$ rRNA coding region of the $E$. coli genome. This fabricated CysFl platform sought to provide improved fundamental characteristics to electrode interface in terms of electro-active surface area and diffusion coefficient. Electrochemical impedance spectroscopy revealed that this genosensor exhibits a linear response to complementary DNA in the concentration range of $10^{-6}$ to $10^{-15} \mathrm{M}$ with a detection limit of $1 \times 10^{-15} \mathrm{M}$. Under optimal conditions, this genosensor was found to retain about $88 \%$ of its initial activity after being used for 6 times.
\end{abstract}

\section{Introduction}

Micro-organisms, such as bacteria and viruses, are widely found in food, soil, water and the intestinal tracts of humans and animals. ${ }^{1}$ Some of these micro-organisms play a crucial role in nature, but some can have intense negative effects on both animals and humans. ${ }^{2}$ Among them entero-hemorrhagic Escherichia coli (E. coli $\mathrm{O} 157: \mathrm{H7}$ ) is a major food-borne and waterborne pathogen that causes diarrhea, hemorrhagic colitis, and hemolytic uremic syndrome. ${ }^{3,4}$ The traditional methods reported for the detection of $E$. coli $\mathrm{O} 157: \mathrm{H} 7$ in food and water include cultures using selective media, ${ }^{5}$ serotyping ${ }^{6,7}$ and PCR amplification. ${ }^{8,9}$ Although these methods exhibit high accuracy, but the operating procedure is complex, time consuming and some techniques even have limited sensitivity and specificity. ${ }^{\mathbf{1 0}}$ Hence, it is necessary to fabricate a sensitive, specific and rapid detection technique for $E$. coli which would have implications in environmental monitoring, food industry and clinical chemistry. Currently, surface plasmon resonance, ${ }^{\mathbf{1 1}}$ quartz crystal microbalance, ${ }^{12}$ and electrochemical ${ }^{13,14}$ transduction techniques have been proposed as substitutes to these conventional methods. Among them, electrochemical nucleic acid biosensing has attracted considerable interest because of its unique

${ }^{a}$ Biomedical Instrumentation Section, CSIR-National Physical Laboratory, New Delhi-110012, India. E-mail: sumanagajjala@gmail.com; Tel: +91-11-45609152

${ }^{b}$ Department of Chemistry, Faculty of Science, Banaras Hindu University, Varanasi221005, India

$\uparrow$ Electronic supplementary information (ESI) available. See DOI: 10.1039/c4ra04511d properties of simplicity, rapidity, accuracy, low cost and portability. ${ }^{15,16}$ Electrochemical biosensors detect nucleic acid binding events on a solid-state transducer surface by monitoring electrochemical spectrum change. ${ }^{16-18}$

In the fabrication of high performance biosensors for clinical diagnostics, the structure and morphology of the matrices and the immobilization of bio-analytes for achieving rapid and sensitive detection of bio-recognition is a major challenge. ${ }^{19}$ In view of the motivating phenomena occurring at ordered microstructures and nanoscale materials, significant work has recently been directed towards the synthesis of novel materials and exploring their applications in a variety of important fields including catalysis, point of care diagnostics for infectious diseases and therapeutics. ${ }^{\mathbf{1 3 , 2 0 , 2 1}}$ Presently, nanomaterials have been widely used as signal amplification mediums to enhance the limit of DNA detection. ${ }^{22,23}$ In this context, the synthesis of polyaniline nanotubes has been reported that can detect nucleic acids with a detection limit of $1.0 \mathrm{fM} .^{24}$ The fabrication of a nanoporous gold electrode using encoded gold nanoparticles achieved a detection limit of about $28 \mathrm{aM}^{25} \mathrm{~A}$ labelfree DNA sensor has also been prepared using gallium nitride nanowires, revealing picomolar concentrations of target DNA. ${ }^{26}$ Wang et al. have fabricated a gold nanoflower modified electrochemical DNA biosensor capable of detecting target DNA with a detection limit of $1 \mathrm{pM}^{27}$ There are reports on the modification of electrodes by different nanomaterials to improve DNA detection but the strategies adopted for these modifications are relatively complex. The modification of the surface using surfactant or polymer matrix in the preparation and assembly of nanomaterials often causes some vague effects 
in DNA detection. ${ }^{28}$ Thus, it is necessary to develop a simple strategy for the construction of nanostructure modified electrodes for improved and sensitive detection of DNA. In this context, very few reports are available on the application of hierarchical structures of organic and related compounds for the fabrication of nucleic-acid biosensors. These hierarchically structured materials not only possess structural organization at various scales but they also lead to improved material properties and performance in terms of high surface area, synergistic interactions, and multiple functionalities. ${ }^{29,30}$ Further, the ability to design these hierarchical structures from materials with self-assembling properties at the nanometer scale opens up new opportunities for application in the field of biosensors. $^{31,32}$

Previously, we reported the detection of nucleic acids using micro-structured cystine dendrites, wherein the role of functional groups and the morphology of dendritic cystine were discussed. ${ }^{33}$ However, there is a lot of scope in tailoring the order and morphology of the amino acid for enhancing the sensitivity and stability of the biosensor. Therefore, in the present work, detailed experiments have been carried out to explore the complexation efficiencies of the binding of DNA strands with probe molecules that are immobilized on cystine flowers (CysFls). These CysFls are being considered as model systems because of their intriguing properties such as the ease of preparation, less chemical handling, and they have a common functionality at one end of the molecule, which is coupled to a range of gradually differentiated functionalities at the other. Further, this CysFl has been utilized to fabricate a label free electrochemical genosensor by covalently immobilizing a specific probe oligonucleotide that is identified from the 16s rRNA coding region of the $E$. coli genome. This CysFl-based platform was found to possess increased electro-active surface area and high electron transport at the electrode-electrolyte interface, enhancing the sensitivity of the genosensor.

\section{Materials and methods}

\subsection{Chemicals and oligonucleotides}

L-Cysteine (analytical grade, 98.5\%), $N$-hydroxysuccinimide (NHS), $\quad N$-ethyl- $N$-(3-dimethylaminopropyl carbodiimide) (EDC), and all other reagents and solvents were procured from Sigma-Aldrich (India). Probe sequence specific to $E$. coli that identified from the 16s rRNA coding region of the $E$. coli genome, complementary, non-complementary and one-base mismatch target sequences were procured from Sigma Aldrich, Milwaukee, USA and are as follows: ${ }^{13}$ DNA probe (pDNA): $\mathrm{NH}_{2}-5^{\prime}$-GGT CCG CTT GCT CTC GC-3' complementary (cDNA): $5^{\prime}$-GCG AGA GCA AGC GGA CC-3' non-complementary: 5'-CTA GTC GTA TAG TAG GC-3' one-base mismatch: $5^{\prime}$-GCG AGA GAA AGC GGA CC-3'.

The bacterial culture samples of other water borne pathogens were provided by the All India Institute of Medical Sciences (AIIMS), New Delhi, India. The solutions of oligonucleotides were prepared in Tris-EDTA buffer (1 M Tris-HCl, 0.5 M EDTA) at $\mathrm{pH} 8.0$ and stored at $-20{ }^{\circ} \mathrm{C}$ prior to use.

\subsection{Synthesis of cystine flowers (CysFls)}

For the synthesis of the CysFls, $100 \mathrm{mM}$ L-cysteine aqueous solution was prepared by maintaining the $\mathrm{pH}$ at 8.0 using sodium bicarbonate. The solution was sonicated for $30 \mathrm{~min}$ at $25{ }^{\circ} \mathrm{C}$ using an ultrasonic bath, and the crystal growth of the CysFls was observed by maintaining the solution at $25{ }^{\circ} \mathrm{C}$ for $12 \mathrm{~h}$. For TEM analysis, the prepared CysFl was dropped onto a carbon grid and dried at room temperature.

\subsection{Fabrication of $\mathrm{CysFl} / \mathrm{Au}$ electrode}

The gold $(\mathrm{Au})$ electrode $\left(0.5 \mathrm{~cm}^{2}\right.$ diameter $)$ was washed in boiling 2.0 $\mathrm{M}$ aqueous $\mathrm{KOH}$ for about $1 \mathrm{~h}$, followed by ultrasonication in piranha solution $\left(3: 1 \mathrm{H}_{2} \mathrm{SO}_{4}-\mathrm{H}_{2} \mathrm{O}_{2}\right)$ for $10 \mathrm{~min}$. The electrode was voltammetrically cycled and characterized in $0.2 \mathrm{M} \mathrm{H}_{2} \mathrm{SO}_{4}(-0.5 \mathrm{~V}$ to $-1.4 \mathrm{~V} v s$. $\mathrm{Ag} / \mathrm{AgCl})$ at a scan rate of $0.10 \mathrm{~V} \mathrm{~s}^{-1}$ until a stable cyclic voltammogram was obtained. The self-assembly of the CysFls was achieved by dipping a precleaned gold electrode into $100 \mathrm{mM}$ CysFl solution overnight $(12 \mathrm{~h})$ at $27{ }^{\circ} \mathrm{C}$. After that, the electrodes were removed and washed repeatedly with de-ionized water.

\subsection{Immobilization of probe DNA and hybridization with target DNA}

The fabricated $\mathrm{CysFl} / \mathrm{Au}$ electrode was activated using EDC ( $2 \mathrm{mM})$ and NHS ( $5 \mathrm{mM})$ and kept for $1 \mathrm{~h}$ in the dark. Subsequently, $40 \mu \mathrm{l}$ of pDNA $\left(10^{-6} \mathrm{M}\right)$ was immobilized onto the modified electrode at $100 \%$ humidity at room temperature $\left(\sim 27^{\circ} \mathrm{C}\right)$ for about $6 \mathrm{~h}$, followed by rinsing with Tris-HCl. The hybridization studies were performed as a function of target DNA concentration with complementary, non-complementary and one-base mis-match sequences in a humid chamber for about $20 \mathrm{~min}$ at $35{ }^{\circ} \mathrm{C}$. The proposed mechanism for the synthesis of a CysFl and the fabrication of the nucleic acid sensor for $E$. coli detection is shown in Scheme 1.

\subsection{Extraction of DNA from bacterial clinical samples}

The extraction of DNA was conducted from a panel of strains comprising E. coli, Salmonella typhimurium, Neisseria meningitides, and Shigella dysenteriae. For this process, the suspensions of the colonies were vortexed by pouring them into $100 \mu \mathrm{l}$ of sterile MilliQ water. The suspension was boiled for $10 \mathrm{~min}$ and then centrifuged at $10000 \mathrm{rpm}$ for $5 \mathrm{~min}$, followed by the addition of an equal volume $(100 \mu \mathrm{l})$ of $24: 1(\mathrm{v} / \mathrm{v})$ chloroformiso-amyl alcohol. The solution was again centrifuged (12 000 $\mathrm{rpm}, 10 \mathrm{~min}$ ), which resulted in the formation of an aqueous layer containing DNA which was carefully pipetted out and maintained at $-20{ }^{\circ} \mathrm{C}$ prior to use..$^{33}$

\subsection{Pre-treatment of extracted DNA}

All the bacterial clinical samples were prepared in Tris-EDTA buffer and were denatured by heating in a water bath $\left(95^{\circ} \mathrm{C}\right)$ for $5 \mathrm{~min}$ and were immediately chilled in ice to obtain the denatured single-stranded DNA. These aliquots of samples were subjected to sonication ( $15 \mathrm{~min}$ at $120 \mathrm{~V}$ ) to break the long DNA strands into smaller fragments. ${ }^{2}$ 

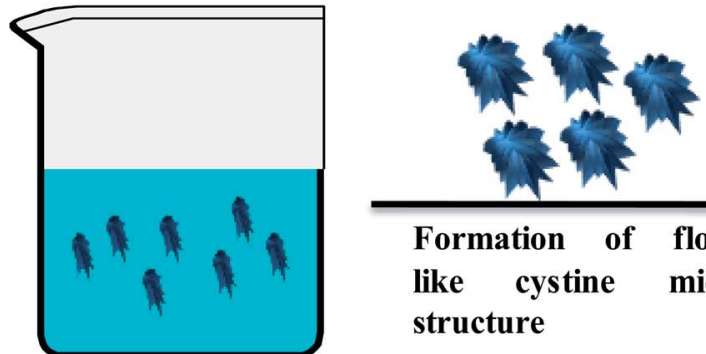

Formation of flower like cystine microstructure
L-Cysteine aqueous solution

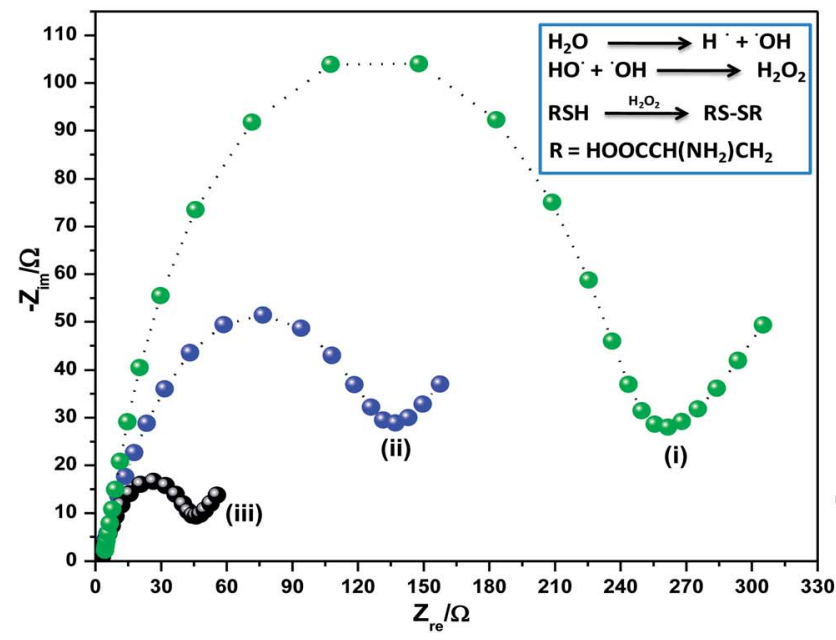

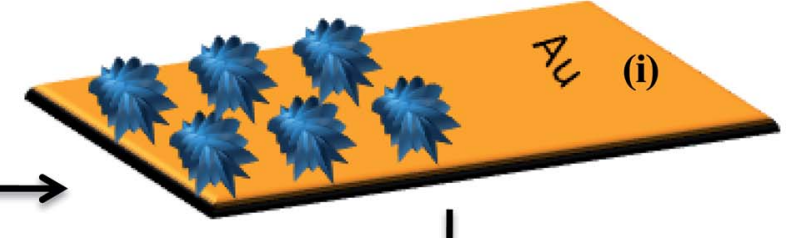

Probe DNA

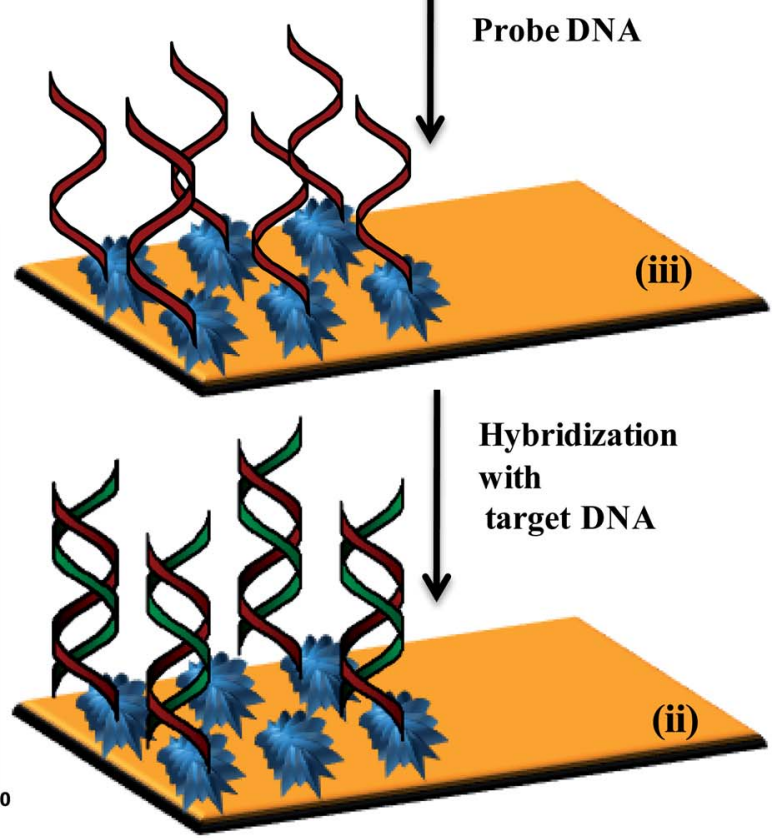

Scheme 1 Schematic showing the synthesis and fabrication of $\mathrm{CysFl}$ and the pDNA/CysFl/Au bioelectrode

\subsection{Characterization}

The structural and morphological investigations of CysFl were carried out using X-ray diffraction (XRD, $\mathrm{Cu} \mathrm{K} \alpha$ radiation, Rigaku, miniflax 2) and transmission electron microscopic (TEM, Hitachi Model, H-800) studies. The scanning electron microscopic (SEM) images were recorded using a JEOL-JSM$6700 \mathrm{~F}$ field-emitting scanning electron microscope (FESEM, $15 \mathrm{kV}$ ). Contact angle (CA) measurements were obtained using a contact angle meter (Data Physics OCA15EC). Fourier transform infra-red (FT-IR) spectroscopy measurements were carried out using a Perkin-Elmer spectrometer (Model Spectrum BX) at $25{ }^{\circ} \mathrm{C}$. Electrochemical analysis was carried out on an Autolab potentiostat/galvanostat (Eco Chemie, Netherlands) using a three-electrode cell with $\mathrm{Au}$ as the working electrode, platinum as the auxiliary electrode and $\mathrm{Ag} / \mathrm{AgCl}$ as the reference electrode in phosphate buffer saline (PBS, $100 \mathrm{mM}, \mathrm{pH} 7.0,0.9 \% \mathrm{NaCl}$ ) containing $5 \mathrm{mM}\left[\mathrm{Fe}(\mathrm{CN})_{6}\right]^{3-/ 4-}$.

\section{Results and discussion}

\subsection{Characterization of CysFl}

The powder XRD pattern of CysFl is displayed in Fig. 1A. The main diffraction peaks of the CysFl structures appear at $18.8^{\circ}$, $28.4^{\circ}, 33.0^{\circ}$ and $34.3^{\circ}$ corresponding to $100,001,112$, and 116 , respectively. The diffraction peaks show a pure hexagonal phase, which is in good agreement with the standard value for bulk hexagonal L-cystine (JCPDS 261776). ${ }^{33,34}$ FTIR spectroscopy was used to characterize CysFl and the pDNA/CysFl/Au electrode in the frequency region of $400-1800 \mathrm{~cm}^{-1}$. The characteristic bands of CysFl seen at $1490 \mathrm{~cm}^{-1}$ are attributed to the presence of amino groups. Intense absorption peaks at 1590 $\mathrm{cm}^{-1}, 1624 \mathrm{~cm}^{-1}$ and $1420 \mathrm{~cm}^{-1}, 1490 \mathrm{~cm}^{-1}$ may be assigned to the asymmetric deformation of $\mathrm{NH}_{3}{ }^{+}$and the asymmetric stretching of $\mathrm{COO}^{-}$, respectively. Bands observed at $1420 \mathrm{~cm}^{-1}$, $1295 \mathrm{~cm}^{-1}$ and $782 \mathrm{~cm}^{-1}$ are attributed to $\mathrm{CH}_{2}-\mathrm{CO}$ deformation, $\mathrm{CH}_{2}$ wagging and rocking vibrations, respectively, confirming the presence of $\mathrm{CH}_{2}$ groups (Fig. 1B). ${ }^{32,33}$ After the immobilization of pDNA on $\mathrm{CysFl}$, the nitrogen base region (1700-1500 $\left.\mathrm{cm}^{-1}\right)$ in the DNA spectrum overlaps with the amine signals of CysFl. The absorption bands seen at 1330 and $1133 \mathrm{~cm}^{-1}$ may be attributed to the anti-symmetric and symmetric stretching vibrations of the phosphate groups, respectively (Fig. 1C). Further, the IR absorption peak at 1048 $\mathrm{cm}^{-1}$ is because of the vibration of ribose (C-C sugar), and the absorption at $903 \mathrm{~cm}^{-1}$ is an indication of the immobilization of DNA on the surface of CysFl.

\subsection{Microscopic analysis of the CysFl}

TEM studies have been carried out to study the formation of CysFl. Fig. 2A shows that the CysFl consists of several hexagonal 

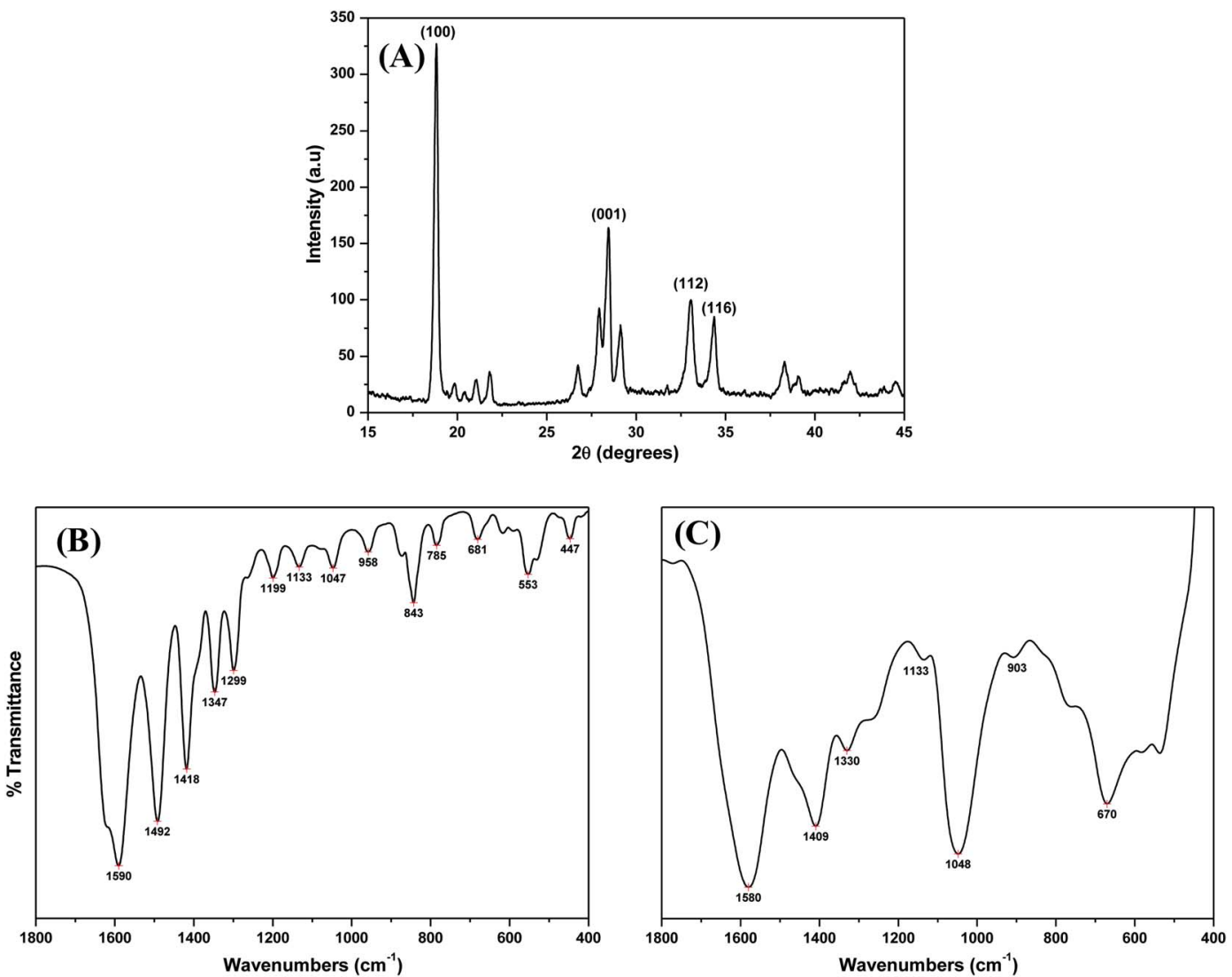

Fig. 1 (A) X-ray diffraction pattern of CysFl. FT-IR spectra of (B) CysFl/Au electrode, and (C) pDNA/CysFl/Au bioelectrode.
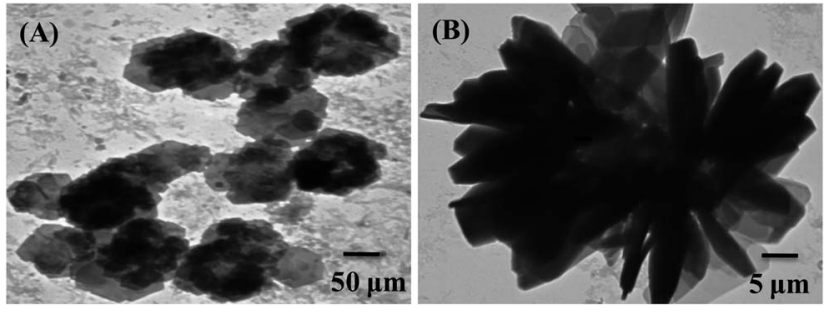

Fig. 2 TEM image showing (A) the formed CysFl at pH 8.0 and $100 \mathrm{mM}$ concentration and (B) the arrangement of hexagonal petals in CysFl.

structures arranged in an ornate manner, where the size of each flower is $50 \mu \mathrm{M}$. High resolution TEM images show that the thickness of each hexagonal flake is about $1 \mu \mathrm{M}$ (Fig. 2B) and they are arranged facial to each other. TEM studies reveal that the growth of these CysFls start with the formation of cystine hexagons, and with an increase in the reaction time these primary hexagonal cystine crystals agglomerate and result in the formation of flower-like structures..$^{32}$ The formation of these structures can be attributed to acoustic cavitations, and the mechanism is described elsewhere. ${ }^{33}$ It appears that the intermolecular electrostatic interactions of hydrogen bonding are responsible for the formation of $\mathrm{CysFl}$, which depends on the change in $\mathrm{pH}^{35}$

\subsection{Morphological characterization of the $\mathrm{CysFl} / \mathrm{Au}$ and pDNA/CysFl/Au electrodes}

The surface morphological studies of the CysFl/Au and DNA/ $\mathrm{CysFl} / \mathrm{Au}$ bioelectrodes were investigated using SEM. Fig. 3A shows the self-assembly of CysFl onto gold surface, where the assemblies are formed in isolation and are not connected. The high magnification image shows that each flower consists of several hexagonal flakes arranged in a patterned manner (Fig. 3A, inset). After the immobilization of pDNA on the CysFl/ Au electrode, a shiny morphology is observed (Fig. 3B), showing the complete coverage of CysFls by pDNA. This increase in the chemically accessible area may be due to well-oriented functional groups present in the CysFl which help in the covalent binding of the amino terminated pDNA.
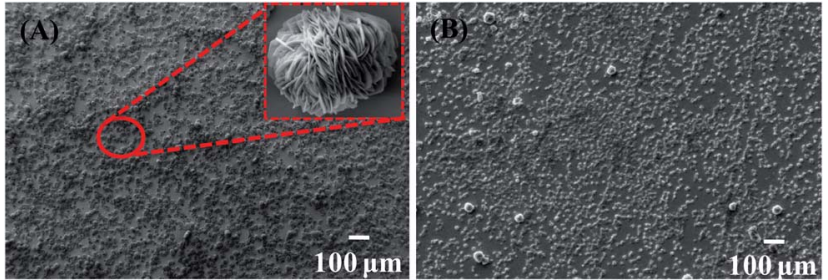

Fig. 3 SEM image of (A) CysFl/Au electrode, and (B) pDNA/CysFl/Au bioelectrode. 


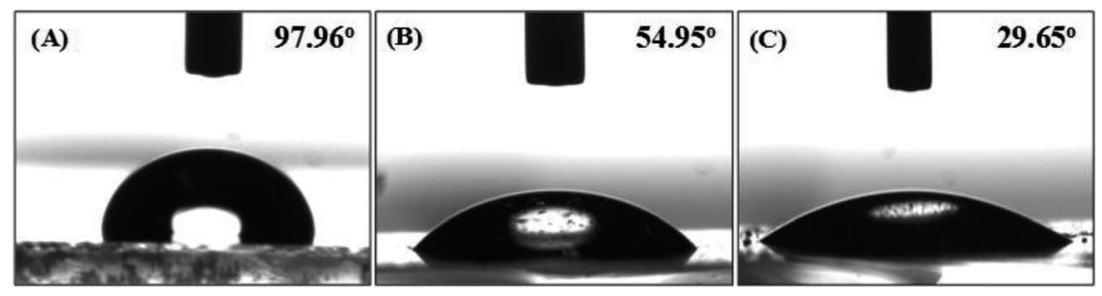

Fig. 4 Contact angle measurements of (A) Au electrode, (B) CysFl/Au electrode, and (C) pDNA/CysFl/Au bioelectrode.

\subsection{Contact angle (CA) studies for Au, CysFl/Au and pDNA/ CysFl/Au electrodes}

To investigate the immobilization of pDNA onto CysFl/Au electrode, CA measurements were carried out using the sessile drop method. The change in contact angle reveals the hydrophobic/hydrophilic character of the surface, which in turn can be related to CysFl self-assembly and pDNA immobilization on the CysFl/Au electrode. Table S1 $\uparrow$ shows the CA data of bare $\mathrm{Au}, \mathrm{CysFl} / \mathrm{Au}$ and pDNA/CysFl/Au bioelectrodes. It can be seen that the value of CA decreases after the self-assembly of CysFl (Fig. 4B) onto the Au electrode (Fig. 4A), indicating the presence of numerous hydrophilic functional groups $\left(-\mathrm{COOH},-\mathrm{NH}_{2}\right.$ and $-\mathrm{SH}$ ) in CysFl. CA measurements were also performed to confirm the immobilization of pDNA onto the CysFl/Au electrode, and it was found that with the progress of the immobilization process, the surface becomes more hydrophilic because of the presence of the phosphodiester backbone of pDNA. The CA value subsequently decreases with time $(4-18 \mathrm{~h})$ and becomes constant at $29.65^{\circ}$ (Fig. 4C) after about 6 h revealing that the complete immobilization of the probe occurs in this time frame.

\subsection{Electrochemical characterization}

3.5.1. Electrochemical impedance spectroscopy studies. Electrochemical impedance spectroscopy (EIS) is a powerful and sensitive tool for studying the charge transfer processes occurring at the electrode-solution or modified electrodesolution interfaces. ${ }^{36}$ In the Nyquist plot of impedance spectra, the semicircle corresponds to the electron transfer resistance process $\left(R_{\mathrm{ct}}\right)$, which usually depends on the dielectric and insulating features at the electrode-electrolyte interface. ${ }^{37,38}$

Fig. 5 shows the EIS studies of the CysFl/Au electrode, EDC/ NHS activated CysFl/Au electrode and $\mathrm{pDNA} / \mathrm{CysFl} / \mathrm{Au}$ bioelectrode in phosphate buffer (100 mM, pH 7.0, 0.9\% $\mathrm{NaCl}$ ) containing $5 \mathrm{mM}\left[\mathrm{Fe}(\mathrm{CN})_{6}\right]^{3-/ 4-}$ as a redox marker. The equivalent circuit (Fig. 5, inset) and the calculated values for solution resistance $\left(R_{\mathrm{S}}\right)$, constant phase element $\left(C_{\mathrm{PE}}\right)$, and warburg impedance $(W)$ value, corresponding to different modifications are given in Table $\mathrm{S} 2 . \dagger$ In the impedance spectra, the low frequency semi-circle is the characteristic of an interfacial charge transfer reaction. The surface modification of the Au electrode with CysFl results in an increase of the $R_{\mathrm{ct}}$ value $(250.4 \Omega$, curve (i)). This increase in the $R_{\mathrm{ct}}$ value is because of the presence of negative charges from the $-\mathrm{COO}^{-}$groups of $\mathrm{CysFl}$ that interrupt the interfacial electron-transfer rate between the electrode and the electrolyte solution. Interestingly, when the CysFl/Au electrode was activated with EDC/NHS, there was a decrease in the $R_{\mathrm{ct}}$ value, which may be attributed to the blocking of the negative charges of the $\mathrm{COO}^{-}$groups of $\mathrm{CysFl}$, and the available net positive charges attract negative redox markers, resulting in the decrease of $R_{\mathrm{ct}}\left(16.7 \Omega\right.$, curve (iv)). ${ }^{33}$ When the pDNA was immobilized on the CysFl/Au electrode there was an increase in the $R_{\text {ct }}$ value ( $47.54 \Omega$, curve (iii)) that could be attributed to the repellence of the redox probe from the approaching electrode surface by the negatively charged phosphate skeletons of DNA. Further, when the pDNA is incubated with its cDNA sequence, hybridization occurs and more negatively charged phosphate backbones are introduced, resulting in an increase of $R_{\mathrm{ct}}(149.3$ $\Omega$, curve (ii)).

3.5.2. Cyclic voltammetry studies. To investigate various kinetic parameters, the cyclic voltammograms of the pDNA/ $\mathrm{CysFl} / \mathrm{Au}$ electrode were recorded as a function of scan rate (10-300 $\left.\mathrm{mV} \mathrm{s}^{-1}\right)$. It was observed that the magnitude of the electrochemical response current [anodic $\left(I_{\mathrm{pa}}\right)$ and cathodic $\left(I_{\mathrm{pc}}\right)$, Fig. $\left.\mathrm{S} 1 \mathrm{~A} \dagger\right]$ for the bioelectrodes is linearly dependent on the scan rate and follows eqn (1) and (2). The separation of the peaks suggests that the process is not perfectly reversible;

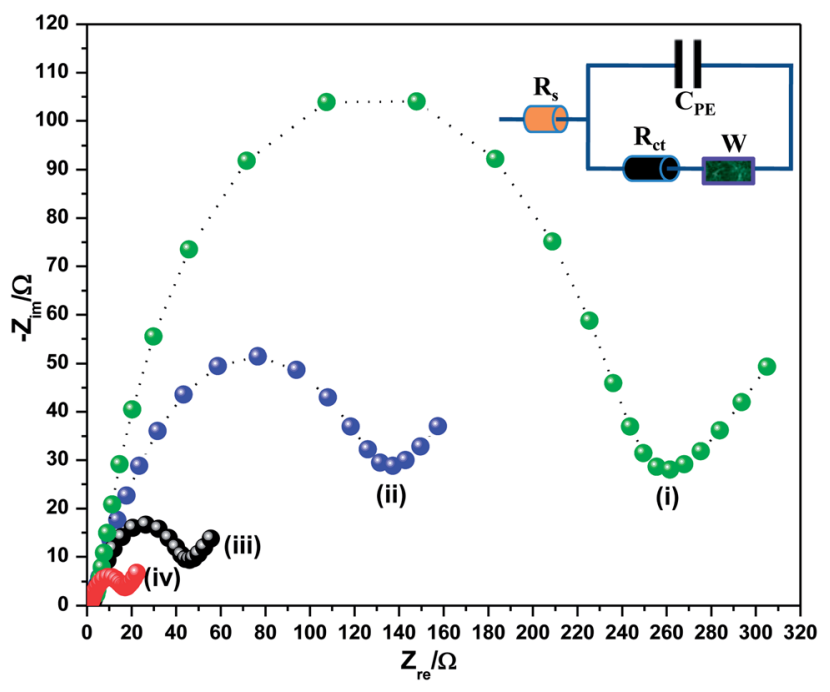

Fig. 5 EIS showing the Nyquist diagram $\left(Z_{\text {im }}\right.$ versus $\left.Z_{\text {re }}\right)$ for Faradic impedance measured in $5 \mathrm{mM}\left[\mathrm{Fe}(\mathrm{CN})_{6}\right]^{3-14-} \mathrm{PBS}$ solution at $\mathrm{pH} 7.0$ at frequency ranging from $10^{5} \mathrm{~Hz}$ to $0.1 \mathrm{~Hz}$ (i) CysFl/Au electrode (ii) complementary DNA incubated on pDNA/CysFl/Au bioelectrode (iii) pDNA/CysFl/Au bioelectrode (iv) EDC/NHS activated CysFl/Au electrode. 
however, stable redox peak current and position during repeated scans at a particular scan rate suggests that CysFlbased electrodes exhibit a quasi-reversible process. ${ }^{37}$ It was also observed that the magnitude of both anodic $\left(E_{\mathrm{a}}\right)$ and cathodic peak $\left(E_{\mathrm{c}}\right)$ potentials (Fig. S1B $\dagger$ ) increases linearly as a function of scan rate (eqn (3) and (4)), which reveals that electron transport from redox moieties to the electrode is very facile.

$I_{\mathrm{pa}}(\mathrm{A})[\mathrm{pDNA} / \mathrm{CysFl} / \mathrm{Au}]=4.8957 \times 10^{-5}(\mathrm{~A})+5.3112 \times 10^{-5} \mathrm{~A}$ $\left(\mathrm{s} \mathrm{mV}^{-1}\right)\left[\right.$ scan rate $\left.\left(\mathrm{mV} \mathrm{s}^{-1}\right)\right] R=0.9986, \mathrm{SD}=1.208 \times 10^{-5}$

$I_{\mathrm{pc}}(\mathrm{A})[\mathrm{pDNA} / \mathrm{CysFl} / \mathrm{Au}]=-1.1785 \times 10^{-4}(\mathrm{~A})-3.542 \times 10^{-5}$ $\mathrm{A}\left(\mathrm{s} \mathrm{mV}^{-1}\right)\left[\right.$ scan rate $\left.\left(\mathrm{mV} \mathrm{s}^{-1}\right)\right] R=0.9920, \mathrm{SD}=1.8612 \times 10^{-5}$

$$
\begin{aligned}
& E_{\mathrm{a}}(\mathrm{V})[\mathrm{pDNA} / \mathrm{CysFl} / \mathrm{Au}]=0.1302(\mathrm{~V})+0.4606(\mathrm{~V}) \\
& \quad \times \log [\mathrm{scan} \text { rate }]
\end{aligned}
$$

$$
\begin{aligned}
& E_{\mathrm{c}}(\mathrm{V})[\mathrm{pDNA} / \mathrm{CysF} / \mathrm{Au}]=0.1181(\mathrm{~V})-0.0384(\mathrm{~V}) \\
& \quad \times \log [\mathrm{scan} \text { rate }]
\end{aligned}
$$

On the basis of the linear slope of anodic peak currents on the square root of potential sweep rates (Fig. S1B $\dagger$ ), it is clear that ion transport from the bulk to the electrode surface occurs exclusively by diffusion. ${ }^{39}$ Further, the diffusion coefficient is calculated by a concentration gradient of $\left[\mathrm{Fe}(\mathrm{CN})_{6}\right]^{3-/ 4-}$ ions between the bulk and the interface, which can be calculated using the Randles-Sevick equation:

$$
I_{\mathrm{p}}=\left(2.99 \times 10^{5}\right) \alpha^{1 / 2} n^{3 / 2} \mathrm{ACD}^{1 / 2} \nu^{1 / 2}
$$

The diffusion coefficient for the pDNA/CysFl/Au electrode is calculated to be $7.19 \times 10^{-6} \mathrm{~cm}^{2} \mathrm{~s}^{-1}$ and for the $\mathrm{CysFl} / \mathrm{Au}$ electrode it was found to be $1.02 \times 10^{-5} \mathrm{~cm}^{2} \mathrm{~s}^{-1}$. From the abovementioned kinetics calculation it can be inferred that the $\mathrm{CysFl} / \mathrm{Au}$ assembly is expected to provide improved electron transfer kinetics to the electrode interface.

\subsection{Electrochemical response studies}

3.6.1. Response studies of the pDNA/CysFl/Au bioelectrode. The sensitivity of the $\mathrm{pDNA} / \mathrm{CysFl} / \mathrm{Au}$ bioelectrode was investigated using EIS by varying the cDNA concentration from $10^{-6} \mathrm{M}$ to $10^{-15} \mathrm{M}$ (Fig. 6A). It was found that with the change in cDNA concentration, there was a change in the $R_{\mathrm{ct}}$ value. This signifies that the hybridization reaction is occurring at the bioelectrode because of which there is increased accumulation of negatively charged phosphate backbones; hence, the $R_{\mathrm{ct}}$ value increases with the formation of double stranded DNA. The difference $\left(\Delta R_{\mathrm{ct}}=R_{\mathrm{ct}(\mathrm{cDNA})}-R_{\mathrm{ct}(\mathrm{pDNA})}\right)$ between the value of the pDNA immobilized electrode and that after hybridization with cDNA has been used as the measurement signal. The analytical signal $\left(\Delta R_{\mathrm{ct}}\right)$ shows a linear relationship with the logarithmic value of complementary target DNA concentration ranging from $10^{-15}$ to $10^{-6} \mathrm{M}$ (Fig. 6B) and follows eqn (6):

$$
\Delta R_{\mathrm{ct}}=161.47+9.07 \log \mathrm{cDNA}
$$
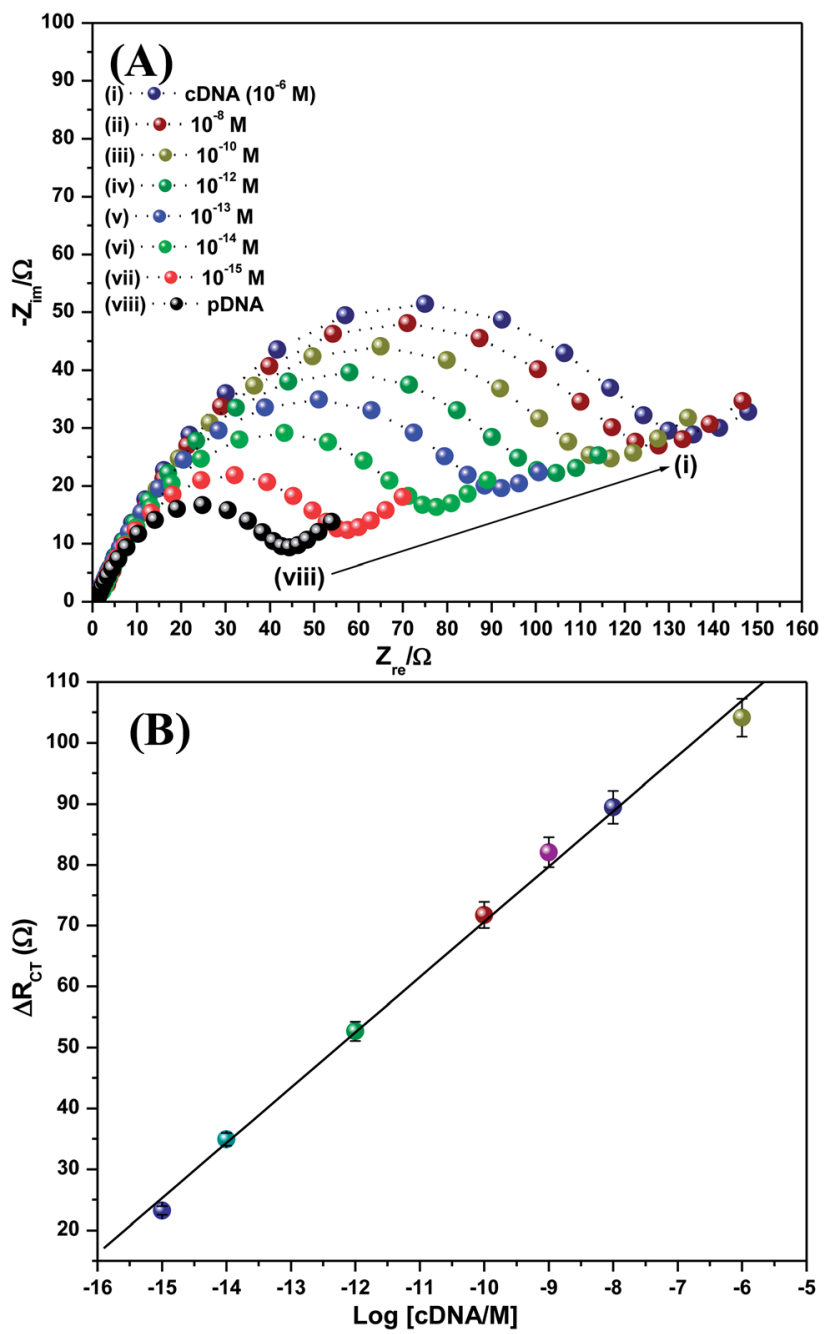

Fig. 6 EIS response of (A) pDNA/CysFl/Au bioelectrode as a function of CDNA concentration $\left(10^{-6}\right.$ to $\left.10^{-15} \mathrm{M}\right)$ in $5 \mathrm{mM}\left[\mathrm{Fe}(\mathrm{CN})_{6}\right]^{3-/ 4-} \mathrm{PBS}$ solution at $\mathrm{pH}$ 7.0. (B) Plot of the ratio of charge transfer resistance after and before hybridization, $R_{\mathrm{ct}}$ target $/ R_{\mathrm{ct}} \mathrm{pDNA}$ of the $\mathrm{pDNA} / \mathrm{CysFl}$ Au bioelectrode vs. the logarithm of target DNA concentrations.

with a linear regression coefficient of 0.998 . The detection limit was calculated to be $1 \times 10^{-15} \mathrm{M}$ using the expression $3 \sigma$, where $\sigma$ was estimated as the standard deviation $(n=10)$ of the impedimetric signals obtained in the absence of bacteria. As the CysFls contain ample functional groups for the immobilization of biomolecules, a higher quantity of pDNA is immobilized onto the $\mathrm{CysFl} / \mathrm{Au}$ electrode, leading to an enhancement in hybridization efficiency. In this case, the pathway of electron transfer to/from the electrode was very effectively blocked and the changes in the $R_{\mathrm{ct}}$ values were remarkably enhanced upon hybridization, leading to a low detection limit. Further, the association constant $\left(K_{\mathrm{a}}\right)$ between cDNA and the pDNA/CysNf/ $\mathrm{Au}$ bioelectrode was estimated from the slope of regression equation and was found to be $0.243 \mathrm{M}^{-1}$ (Fig. S2 $\dagger$ ). ${ }^{40,41}$ The performance of the DNA hybridization detection based on the $\mathrm{pDNA} / \mathrm{CysFl} / \mathrm{Au}$ platform were compared with other hierarchical structure-based biosensors, as shown in Table 1. It was 


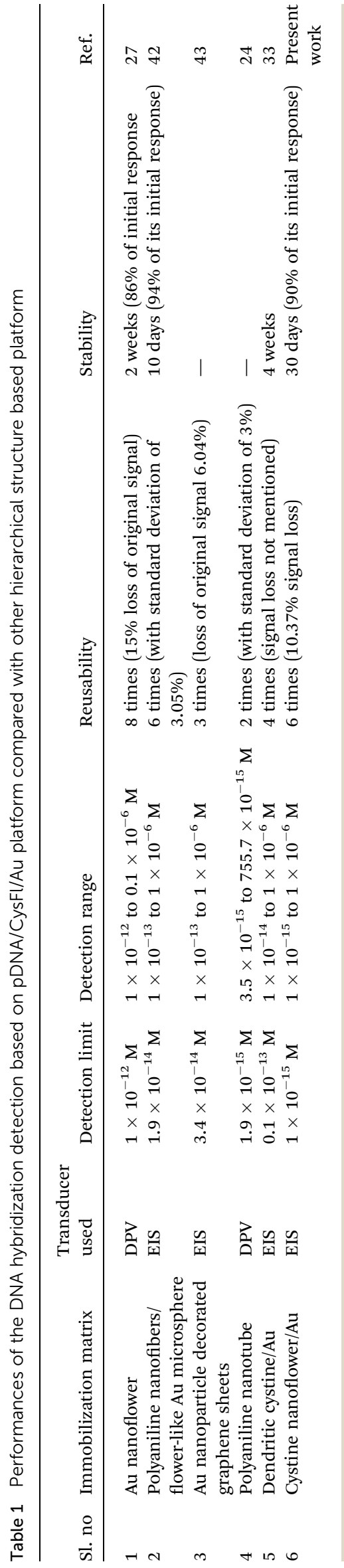

observed that the CysFl-based platform has a lower detection limit and a wider detection range for nucleic acids.

\subsection{Selectivity of the bioelectrode}

The specificity of the pDNA/CysFl/Au bioelectrode towards different target DNA sequences (complementary, noncomplementary and one base mismatch) and culture samples of E. coli, S. typhimurium, N. meningitidis and S. dysenteriae was studied using EIS (Fig. 7). After the incubation of bioelectrode with $E$. coli spiked and $E$. coli culture DNA, there was a marked increase in the semicircle diameter; the $R_{\mathrm{ct}}$ value was nearly the same as that of cDNA, confirming the process of hybridization. When the pDNA/CysFl/Au bioelectrode was incubated with noncomplementary and culture samples of bacterial pathogens DNA, there was a slight or negligible change in the $R_{\mathrm{ct}}$ value with respect to pDNA. Because the non-complementary DNA bases do not match with the pDNA bases, it was expected that no hybridization occurs, and the $R_{\text {ct }}$ should result in a semicircle diameter similar to that of the $\mathrm{pDNA} / \mathrm{CysFl} / \mathrm{Au}$ bioelectrode (Fig. 7, inset). ${ }^{33} \mathrm{~A}$ slight increase in $R_{\mathrm{ct}}$ for $S$. typhimurium and $N$. meningitidis DNA was observed, which may be because of nonspecific DNA interactions with the pDNA/CysFl/Au bioelectrode surface, leading to an increase in negative charges on the electrode surface. When the pDNA/CysFl/Au bioelectrode was exposed to the one base mis-match DNA sequence, there was a slight increase in the semicircle diameter in comparison to that of the pDNA. This may be because of the partial hybridization of pDNA with the complementary bases of the one base mis-match DNA, resulting in increased negative charge of the electrode surface due to the higher blocking effect of the surface or the repulsion of the marker ion. ${ }^{19}$ These results reveal that the fabricated genosensor based on the CysFl/Au platform is highly specific for the detection of $E$. coli $\mathrm{O} 157: \mathrm{H} 7$.

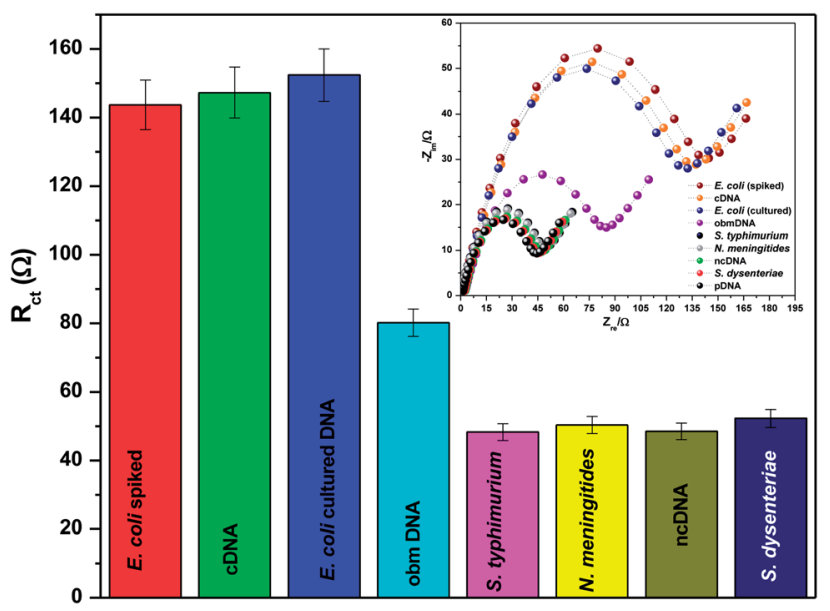

Fig. 7 Bar diagram showing the change in $R_{\mathrm{ct}}$ values for (i) spiked $E$. coli (ii) cDNA (iii) E. coli cultured (ii) one base mismatch (iii) S. typhimurium (iv) N. meningitidis (v) non complementary (iv) S. dysenteriae immobilized onto (v) pDNA/CysFl/Au bioelectrode. Inset figure shows the Nyquist plots for different cultured sample immobilized onto pDNA/CysFl/Au bioelectrode in $5 \mathrm{mM}\left[\mathrm{Fe}(\mathrm{CN})_{6}\right]^{3-/ 4-}$ PBS solution at $\mathrm{pH} 7.0$. 

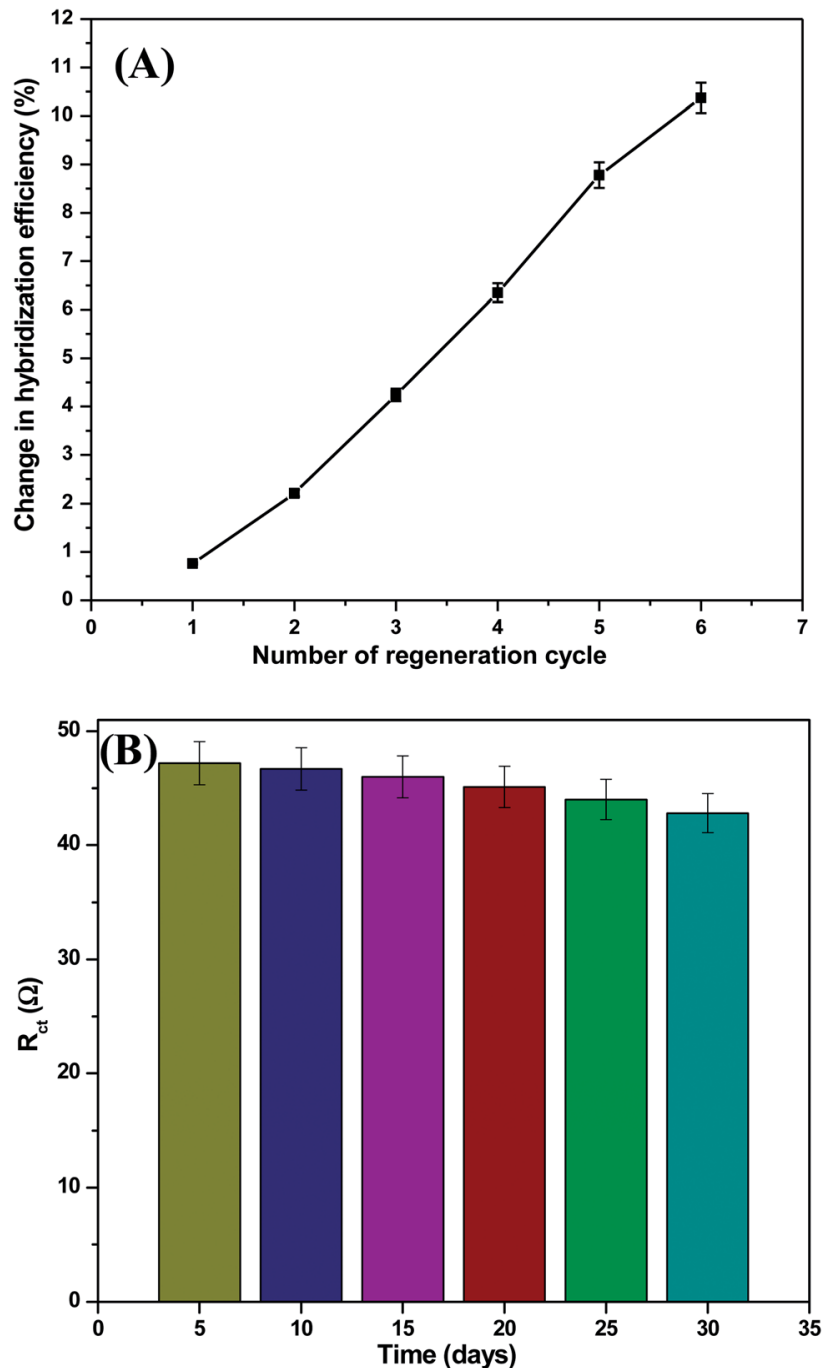

Fig. 8 (A) Percentage change in the $R_{\mathrm{ct}}$ of the fabricated pDNA/CysFl/ Au bioelectrode towards $E$. coli detection was determined after each regeneration cycle (6 cycles). (B) Bar diagram showing the stability of the fabricated pDNA/CysFl/Au bioelectrode.

\subsection{Reusability and stability of the bioelectrode}

The strong binding of pDNA with the CysFl/Au electrode surface shows the stability of the genosensor to allow ready regeneration. For this, the electrode was immersed in a buffer solution ( $\mathrm{pH}$ 8.0) containing Tris- $\mathrm{HCl}(10 \mathrm{mM})$ and EDTA $(1 \mathrm{mM})$ at 100 ${ }^{\circ} \mathrm{C}$ for $5 \mathrm{~min}$, followed by cooling in an ice bath for about 30 min, which completely removed cDNA via thermal denaturation. ${ }^{39}$ The $R_{\text {ct }}$ value of the genosensor was found to decrease after each regeneration process with an average signal loss of about $2 \%$ (Table S3†). This reduction in signal may be due to surface fouling during the regeneration process. The total loss of hybridization signal after 6 cycles is about $15.4 \Omega$, which corresponds to $\sim 11.37 \%$ loss of the initial value, indicating that the bioelectrode reproducibly detects target DNA with repeated uses (Fig. 8A). To investigate the storage stability of the fabricated sensor, five measurements were recorded each week for over 30 days of continuous analysis. The decrease in signal response of the bioelectrode observed was less than $10 \%$ when it was stored at $4{ }^{\circ} \mathrm{C}$ (Fig. 8B).

\section{Conclusions}

In summary, the present work emphasizes the synthesis of cystine flowers prepared using the acoustic cavitation method and their application for $E$. coli detection. The structural and morphological studies provided strong evidence for the formation of CysFl and its self-assembly onto a gold electrode. Label-free detection using an electrochemical impedance spectroscopic technique reveals that the fabricated biosensor with an appropriately optimized protocol can accurately detect E. coli in the range of $10^{-6}$ to $10^{-15} \mathrm{M}$. This fabricated biosensor was found to be selective for $E$. coli detection and retains significant amount of activity (88\% of the initial activity) after using for 6 cycles. Our sensing strategy could be extended for the detection of other micro-organisms and open up new avenues for the designing of electrochemical nucleic acid sensors.

\section{Acknowledgements}

We thank Prof. R.C. Budhani, Director, CSIR-NPL, New Delhi, India for the facilities. C.M.P. is thankful to CSIR, India, for the award of SRF. We thank Dr A.M. Biradar (NPL, New Delhi), Prof. B.D. Malhotra (DTU, Delhi) and Dr A.K. Pandey (PGIMER, Chandigarh) for interesting discussions. Thanks are due to Dr Seema Sood (AIIMS, New Delhi) for providing the bacterial culture samples. The financial support received from DST, (Grant no. DST/TSG/ME/2008/18) India is gratefully acknowledged.

\section{References}

1 P. Leonard, S. Hearty, J. Brennan, L. Dunne, J. Quinn, T. Chakraborty and R. O'Kennedy, Enzyme Microb. Technol., 2003, 32, 3-13.

2 C. M. Pandey, R. Singh, G. Sumana, M. K. Pandey and B. D. Malhotra, Sens. Actuators, B, 2011, 151, 333-340.

3 H. Karch, P. I. Tarr and M. Bielaszewska, Int. J. Med. Microbiol., 2005, 295, 405-418.

4 J. G. Wells, B. R. Davis, I. K. Wachsmuth, L. W. Riley, R. S. Remis, R. Sokolow and G. K. Morris, J. Clin. Microbiol., 1983, 18, 512-520.

5 T. S. Hammack, P. Feng, R. M. Amaguana, G. A. June, P. S. Sherrod and W. H. Andrews, J. AOAC Int., 1997, 80, 335-340.

6 P. A. Chapman, A. T. Malo, C. A. Siddons and M. Harkin, Appl. Environ. Microbiol., 1997, 63, 2549-2553.

7 J. Czajka and C. A. Batt, J. Appl. Microbiol., 1996, 81, 601-607. 8 J. A. Higgins, S. Nasarabadi, J. S. Karns, D. R. Shelton, M. Cooper, A. Gbakima and R. P. Koopman, Biosens. Bioelectron., 2003, 18, 1115-1123.

9 G. Wang, C. G. Clark and F. G. Rodgers, J. Clin. Microbiol., 2002, 40, 3613-3619. 
10 X. Jiang, K. Chen, J. Wang, K. Shao, T. Fu, F. Shao, D. Lu, J. Liang, M. F. Foda and H. Han, Analyst, 2013, 138, 33883393.

11 A. D. Taylor, Q. Yu, S. Chen, J. Ã. Homola and S. Jiang, Sens. Actuators, B, 2005, 107, 202-208.

12 X. Mao, L. Yang, X.-L. Su and Y. Li, Biosens. Bioelectron., 2006, 21, 1178-1185.

13 C. M. Pandey, A. Sharma, G. Sumana, I. Tiwari and B. D. Malhotra, Nanoscale, 2013, 5, 3800-3807.

14 P. Geng, X. Zhang, Y. Teng, Y. Fu, L. Xu, M. Xu, L. Jin and W. Zhang, Biosens. Bioelectron., 2011, 26, 3325-3330.

15 N. Prabhakar, K. Arora, S. K. Arya, P. R. Solanki, M. Iwamoto, H. Singh and B. D. Malhotra, Analyst, 2008, 133, 1587-1592.

16 J. Wang, Anal. Chim. Acta, 2002, 469, 63-71.

17 A. Bonanni and M. del Valle, Anal. Chim. Acta, 2010, 678, 717.

18 C.-z. Li, H. Karadeniz, E. Canavar and A. Erdem, Electrochim. Acta, 2012, 82, 137-142.

19 B. Chen, Y. Xiao, C. Liu, C. Li and F. Leng, Nucleic Acids Res., 2010, 38, 3643-3654.

20 J. Wang, G. Rivas, X. Cai, M. Chicharro, C. Parrado, N. Dontha, A. Begleiter, M. Mowat, E. Palecek and P. E. Nielsen, Anal. Chim. Acta, 1997, 344, 111-118.

21 P. Wagner, M. Hegner, P. Kernen, F. Zaugg and G. Semenza, Biophys. J., 1996, 70, 2052-2066.

22 J. Wang, Anal. Chim. Acta, 2003, 500, 247-257.

23 A. Erdem, Talanta, 2007, 74, 318-325.

24 H. Chang, Y. Yuan, N. Shi and Y. Guan, Anal. Chem., 2007, 79, 5111-5115.

25 K. Hu, D. Lan, X. Li and S. Zhang, Anal. Chem., 2008, 80, 9124-9130.

26 C.-P. Chen, A. Ganguly, C.-H. Wang, C.-W. Hsu, S. Chattopadhyay, Y.-K. Hsu, Y.-C. Chang, K.-H. Chen and L.-C. Chen, Anal. Chem., 2008, 81, 36-42.
27 L. Wang, X. Chen, X. Wang, X. Han, S. Liu and C. Zhao, Biosens. Bioelectron., 2011, 30, 151-157.

28 N. Singh, B. Manshian, G. J. S. Jenkins, S. M. Griffiths, P. M. Williams, T. G. G. Maffeis, C. J. Wright and S. H. Doak, Biomaterials, 2009, 30, 3891-3914.

29 Z. Ren, Y. Guo, C.-H. Liu and P.-X. Gao, Front. Chem., 2013, 1, 18.

30 M. Byun, N. B. Bowden and Z. Lin, Nano Lett., 2010, 10, 31113117.

31 Y.-P. Zhu, T.-Z. Ren, T.-Y. Ma and Z.-Y. Yuan, Int J Photoenergy, 2014, 2014, 15.

32 C. M. Pandey, G. Sumana and I. Tiwari, Biosens. Bioelectron., 2014, 61, 328-335.

33 C. M. Pandey, G. Sumana and B. D. Malhotra, Biomacromolecules, 2011, 12, 2925-2932.

34 J. D. Rimer, Z. An, Z. Zhu, M. H. Lee, D. S. Goldfarb, J. A. Wesson and M. D. Ward, Science, 2010, 330, 337-341.

35 H. Hongliang, W. Chungang, M. Zhanfang and S. Zhongmin, Nanotechnology, 2006, 17, 5163.

36 F. Lisdat and D. Schäfer, Anal. Bioanal. Chem., 2008, 391, 1555-1567.

37 A. Kaushik, A. Vasudev, S. K. Arya and S. Bhansali, Biosens. Bioelectron., 2013, 50, 35-41.

38 A. Kaushik, P. R. Solanki, K. Kaneto, C. G. Kim, S. Ahmad and B. D. Malhotra, Electroanalysis, 2010, 22, 1045-1055.

39 A. Sharma, G. Sumana, S. Sapra and B. D. Malhotra, Langmuir, 2013, 29, 8753-8762.

40 I. Szymanska, H. Radecka, J. Radecki and R. Kaliszan, Biosens. Bioelectron., 2007, 22, 1955-1960.

41 S. K. Arya, T. S. Pui, C. C. Wong, S. Kumar and A. R. A. Rahman, Langmuir, 2013, 29, 6770-6777.

42 X. Wang, T. Yang, X. Li and K. Jiao, Biosens. Bioelectron., 2011, 26, 2953-2959.

43 Y. Hu, S. Hua, F. Li, Y. Jiang, X. Bai, D. Li and L. Niu, Biosens. Bioelectron., 2011, 26, 4355-4361. 